\title{
Kualitas Audit: Ditinjau dari Fee Audit, Risiko Audit dan Skeptisme Profesional Auditor Sebagai Variabel Moderating
}

\author{
Muslim Muslim ${ }^{1}$, Syamsuri Rahim ${ }^{2}$, Muhammad Faisal AR Pelu ${ }^{3}$, Alma Pratiwi ${ }^{*} 4$ \\ 1,2,3,4Universitas Muslim Indonesia, Makassar - Indonesia
}

\section{A R T I C L E IN F O}

Article history:

Received 12 December 2019

Received in revised form 7 June 2020

Accepted 10 June 2020

Available online 29 June 2020

\section{Kata Kunci:}

Kualitas Audit; Fee Audit;

Risiko Audit; Skeptisme

Profesional

Keywords:

Audit Quality, Fee Audit;

Skeptisme of Professional

\begin{abstract}
A B S T R A K
Tujuan Penelitian ini adalah untuk mengetahui pengaruh fee audit dan risiko audit terhadap kualitas audit dengan skeptisme profesional auditor sebagai variabel moderating. Penelitian ini dilakukan pada 8 Kantor Akuntan Publik di Kota Makassar dengan responden sebanyak 40 orang. Metode analisis yang digunakan adalah analisis regresi berganda (Moderated Regression Analysis) yang digunakan untuk mengukur kekuatan hubungan antara dua variabel atau lebih. Hasil penelitian ini menemukan variable fee audit berpengaruh negatif dan tidak signifikan terhadap kualitas audit. Hasil ini memberikan gambaran bahwa semakin tinggi fee audit yang diterima auditor maka kualitas audit akan semakin menurun. Sedangkan risiko audit berpengaruh positif tidak signifikan terhadap kualitas audit. Hasil penelitian ini memberikan gambaran bahwa semakin tinggi risiko audit maka kualitas audit akan semakin menurun. Skeptisme profesional auditor sebagai variabel moderasi tidak mampu memperkuat pengaruh fee audit terhadap kualitas audit. Selanjutnya skeptisme profesional auditor sebagai variabel moderasi juga tidak mampu memperkuat pengaruh risiko audit terhadap kualitas audit
\end{abstract}

The purpose of this study was to determine the effect of audit fees and audit risk on audit quality with auditor professional skepticism as a moderating variable. This research was conducted at 8 public accounting firms in Makassar city with 40 respondents. The analytical method used is multiple regression analysis (Moderated Regression Analysis) which is used to measure the strength of the relationship between two or more variables. The results of this study found that the audit fee variable had a negative and not significant effect on audit quality. These results illustrate that the higher the audit fee received by the auditor, the audit quality will decrease. While audit risk is not a significant positive effect on audit quality. The results of this study illustrate that the higher the audit risk, the audit quality will decrease. The auditor's professional skepticism as a moderating variable is not able to strengthen the effect of audit fees on audit quality. Furthermore, auditor professional skepticism as a moderating variable is also unable to strengthen the effect of audit risk on audit quality 


\section{Pendahuluan}

Laporan keuangan yang relevan dan reliabel merupakan karakteristik informasi yang penting bagi para stakeholder dalam mengambil keputusan. Kesulitan yang masih dialami oleh para stakeholder adalah ketidakmampuannya menganalisis kehandalan informasi yang telah disajikan oleh perusahaan. Kondisi ini tentu membuat para stakeholder sebagai pemakai informasi keuangan membutuhkan jasa pihak ketiga. Suraida (2005:186) mengemukakan bahwa kehadiran auditor adalah sebagai pihak ketiga yang mampu menjembatani berbagai kepentingan dan asimetri informasi antara pihak manajemen perusahaan dan pemilik perusahaan dan dianggap mampu untuk memberikan jaminan bahwa laporan keuangan yang telah disajikan oleh pihak manajemen perusahaan dapat dipercaya dan diandalkan untuk digunakan oleh pemilik perusahaan dan pengguna (user) lainnya dalam pengambilan keputusannya.

Pekerjaan auditor sebagai sebuah pekerjaan profesional di Indonesia dari waktu ke waktu akan terus mengalami tantangan yang semakin berat. Sebagaimana Tarigan, Bangun, \& Susanti, (2013 :804) mengemukakan bahwa pada masa yang akan datang, Kantor Akuntan Publik (KAP) di negeri ini akan bersaing dengan KAP Asing sebagai konsekuensi adanya era globalisasi. Kondisi ini tentu menjadikan wacana tentang kualitas hasil pekerjaan auditor akan menjadi isu sentral dan semakin menarik untuk dibahas agar di masa yang akan datang tercipta kepercayaan para stakeholder terhadap auditor dalam melaksanakan pekerjaannya.

Kasus kegagalan audit yang menimpa perusahaan Kimia Farma pada tahun 2001 silam menjadi catatan tersendiri tentang kegagalan auditor dalam melaksanakan tugasnya. Dalam kasus tersebut terjadi mark up terhadap laba, dimana tahun 2001 ditulis Rp. 132 milyar padahal sebenarnya hanya senilai Rp. 99,594 milyar. Sedangkan pada Bank Lippo terjadi pembukuan ganda pada tahun 2002. Pada tahun tersebut Badan Pengawas pasar Modal menemukan adanya tiga versi laporan keuangan. Laporan yang berbeda itu, pertama, yang diberikan kepada publik atau diiklankan melalui media massa pada 28 November 2002. Kedua, laporan ke BEJ pada 27 Desember 2002, dan ketiga, laporan yang disampaikan akuntan publik, dalam hal ini kantor akuntan publik Prasetio, Sarwoko dan Sandjaja dengan auditor Ruchjat Kosasih dan disampaikan kepada manajemen Bank Lippo pada 6 Januari 2003.

Apa pun tugas yang dilakukan oleh auditor, yang dibutuhkan adalah sebuah hasil kerja yang berkualitas. Diana \& Azlina, (2016 :177) mengemukakan bahwa jika terjadi penurunan kualitas audit maka dampaknya akan terjadi penurunan kepercayaan publik terhadap profesi akuntansi, menurunkan kredibilitas para akuntan publik atas hasil- hasil audit yang mereka lakukan dan pada akhirnya akibat dari penurunan kualitas audit ini dapat mematikan profesi itu sendiri serta akan menimbulkan campur tangan pemerintah yang berlebihan terhadap profesi ini.

Skeptisme profesional merupakan sebuah tuntutan dari pekerjaan profesional seorang akuntan publik dalam melakukan pekerjaannya. Skeptisme profesional didefenisikan sebagai sebuah sikap kritis seorang akuntan publik untuk selalu mempertanyakan dan melakukan evaluasi bukti dan informasi yang diperoleh selama penugasan audit, Oktania \& Suryono, (2013 : 2). Attamimi \& Riduan, (2015:2) kemudian menjelaskan bahwa sikap skeptisme profesional dari akuntan publik akan sangat diperlukan karena masyarakat luas akan menjadi penilai laporan keuangan yang telah diaudit bukan hanya untuk kepentingan klien yang membayar fee tetapi juga untuk pihak ketiga atau masyarakat yang mempunyai berbagai kepentingan terhadap laporan keuangan klien yang diaudit atau diperiksa seperti (pemegang saham, kreditur, investor, calon kreditur, calon investor, dan instansi pemerintah terutama instansi pajak). Oleh karena itu, sikap skeptisme bagi auditor merupakan hal yang pokok untuk diterapkan dalam melaksanakan pekerjannya, meskipun auditor tersebut telah dibayar oleh kliennya karena jasa yang telah diberikan.

Beberapa kasus yang melibatkan beberapa Kantor Akuntan Publik (KAP) di negeri ini membuktikan bahwa sebagian Kantor Akuntan Publik telah melakukan praktik pelanggaran dan menghasilkan kualitas audit laporan keuangan yang rendah. Julianto, Yadnyana, \& Suputra, (2016 : 4031) mengemukakan bahwa kualitas audit yang rendah akan berpengaruh negatif pada citra Kantor Akuntan Publik yang bersangkutan baik bagi klien maupun bagi masyarakat dan umumnya dipengaruhi oleh beberapa aspek salah satunya fee audit. Hartadi, (2012:85) mengemukakan bahwa salah satu fenomena dari berbagai wacana tentang kualitas audit ternyata terbukti secara empiris audit itu lebih disebabkan oleh faktor fee audit, walaupun sampai saat ini belum terdapat peraturan yang mengatur besarnya " $f e e$ " audit yang harus ditagih oleh Auditor Publik terhadap klien (auditee) atas jasa audit yang diberikannya.

Besaran fee audit yang akan diterima oleh auditor merupakan salah satu aspek yang menjadi tanggung jawab auditor dan akan membuat auditor berada di dalam posisi dilematis. Di satu sisi, auditor harus bersikap independen dalam memberi opini mengenai kewajaran laporan keuangan yang berkaitan dengan kepentingan banyak pihak, namun disisi lain auditor juga harus bisa memenuhi tuntutan yang diinginkan oleh klien yang membayar fee atas jasanya agar kliennya puas dengan pekerjaannya dan tetap menggunakan jasanya diwaktu yang akan datang, (Ng dan Tan, 2003; Rohmaniyah, 2016:85). Kata 
Independen yang sudah melekat pada pribadi setiap auditor merupakan sebuah tuntutan profesi akuntan pubik, namun karena klien telah memberikan sejumlah fee maka klien akan mencoba memberikan pengaruh untuk mendukung kepentingannya. Maka dalam kondisi seperti ini sebuah kata independensi yang melekat dalam diri auditor tidak akan lagi berdefinisi secara sempurna, Tandirerung (2012), Rohmaniyah (2016:85).

Risiko dalam proses auditing merupakan suatu tingkat ketidakpastian tertentu dalam pelaksanaan audit, dimana auditor menyadari bahwa dalam pelaksanaan auditnya terdapat ketidakpastian kompetensi bahan bukti, efektivitas struktur pengendalian intern klien dan ketidakpastian apakah laporan keuangan memang telah disajikan secara wajar setelah audit selesai. Johnson, Jamal, \& Glen Berryman (1989) dan Cahyadi (2013: 766) mengemukakan bahwa mempertimbangkan risiko audit merupakan salah satu konsep penting dalam penerapan standar auditing, khususnya standar pekerjaan lapangan, dan standar pelaporan untuk menentukan sifat atau jenis, saat, dan luas prosedur audit. Tujuan audit ialah menekan risiko audit ini ketingkat yang rendah yang dapat diterima auditor (Tuanakotta, 2013;89), Diana \& Azlina, (2016:178). Risiko ini menyatakan suatu ketidakpastian yang dihadapi auditor dimana kemungkinan bahan bukti yang telah dikumpulkan oleh auditor tidak mampu untuk mendeteksi adanya salah saji yang material dan akan berdampak terhadap kualitas audit yang dihasilkan.

Permasalahan mengenai rendahnya kualitas audit menjadi sorotan masyarakat dalam beberapa tahun terakhir dengan adanya keterlibatan akuntan publik didalamnya. Teori keagenan memiliki keterkaitan tentang permasalahan dalam penelitian ini. Teori keagenan ini memperlihatkan bahwa permintaan jasa audit muncul karena adanya konflik kepentingan antara manajemen sebagai agen dan pemegang saham sebagai principal, dan pihak-pihak lain yang mengadakan kontrak dengan klien, Srimindarti (2006 : 64). Auditor dalam hal ini merupakan pihak yang dianggap mampu menjembatani kepentingan principal dan kepentingan agen sebagai pengelola keuangan perusahaan.

Dalam hal keagenan, auditor juga memiliki kepentingan untuk mempertahankan pendapatannya, penetapan fee audit yang tinggi untuk menghasilkan kualitas audit yang tinggi pula. Gravious (2007) dalam Kurniasih \& Rohman, (2014:2) menjelaskan bahwa masalah keagenan auditor sebenarnya bersumber dari mekanisme kelembagaan antara auditor dan manajemen (auditee). Manajemen (auditee) yang menunjuk auditor untuk melakukan audit untuk kepentingan prinsipal (owner), sementara disisi lain, manajer yang membayar dan menanggung jasa audit. hal ini dapat menimbulkan ketergantungan antara auditor dengan klien demi perikatan yang panjang dan mempererat hubungan kedekatan antara auditor dengan klien.

Teori Agensi berhubungan dengan teori biaya transaksi dimana keduanya terdapat penekanan bahwa teori agensi lebih menekankan pada suatu proses kontrak sedangkan teori biaya transaksi menekankan pada kontraknya yang dilakukan antara Akuntan Publik dengan klien Hartadi, (2012). Fee audit didefenisikan sebagai besaran imbal jasa yang diterima oleh auditor akan pelaksanaan pekerjaan audit. Besarnya fee audit yang ditetapkan oleh kantor akuntan publik merupakan salah satu obyek yang menarik untuk diteliti. Hal ini disebabkan kebijakan penentuan fee audit oleh kantor akuntan publik menjadi salah satu aspek dalam review mutu terhadap kantor akuntan publik tersebut. Besar kecilnya fee audit dipengaruhi oleh beberapa faktor antara lain tekanan anggaran waktu, kompleksitas tugas, dan reputasi auditor, Jemada \& Yaniartha, (2013 : 134). Hasil penelitian (Kurniasih \& Rohman, 2014) mengidentifikasi bahwa fee audit memiliki pengaruh positif terhadap kualitas audit. Hal tersebut menunjukkan bahwa semakin tinggi fee audit yang dibebankan oleh perusahaan klien atas jasa audit maka semakin berkualitas audit yang dihasilkan.

\section{H1: Fee Audit Berpengaruh Positif Terhadap Kualitas Audit}

Risiko dalam auditing diartikan bahwa auditor telah menerima suatu tingkat ketidakpastian mengenai kompetensi bahan bukti, efektivitas struktur pengendalian intern klien dan ketidakpastian apakah laporan keuangan memang telah disajikan secara wajar setelah audit selesai, Suraida, (2005: 191). Risiko audit juga terindikasi sebagai faktor berpengaruh terhadap penurunan kualitas audit. Risiko audit (audit risk) adalah risiko memberikan opini audit yang tidak tepat (expressing an inappropriate audit opinion) atas laporan keuangan yang disalah sajikan secara material. Hasil riset Cahyadi P. I. G, (2013:778) menunjukkan bahwa Risiko kesalahan dan kompleksitas audit tidak berpengaruh pada kualitas audit KAP di Bali. Sedangkan hasil berbeda ditemukan oleh Diana \& Azlina, (2016 : 186) bahwa Risiko audit berpengaruh terhadap perilaku penurunan kualitas audit.

\section{H2: Risiko Audit Berpengaruh Positif Terhadap Kualitas Audit}

Skeptisme profesional auditor merupakan sikap (attitude) auditor dalam melakukan penugasan audit dimana sikap ini mencakup pikiran yang selalu mempertanyakan dan melakukan evaluasi secara kritis terhadap bukti audit, Noviyanti, (2008 : 107). Hasil riset Anugerah, (2014: 15) membuktikan bahwa skeptisme profesional berpengaruh terhadap kualitas audit auditor Inspektorat se-Provinsi Riau. Dan 
menjelaskan bahwa tinggi atau rendahnya skeptisme auditor akan mempengaruhi berkualitas atau tidaknya suatu audit yang dihasilkan.

H3: Skeptisme Profesional Mempengaruhi Hubungan Fee Audit Terhadap Kualitas Audit

Hasil riset Diana \& Azlina, (2016 : 186) membuktikan bahwa variabel Risiko audit berpengaruh terhadap perilaku penurunan kualitas audit. Sedangkan hasil riset Hasil riset Anugerah, (2014: 15) membuktikan bahwa skeptisme profesional berpengaruh terhadap kualitas audit auditor Inspektorat seProvinsi Riau.

H4: Skeptisme Profesional Mempengaruhi Hubungan Risiko Audit Terhadap Kualitas Audit

\section{Metode}

Populasi dalam penelitian ini meliputi seluruh jumlah auditor yang terdapat pada KAP yang berdomisili di Kota Makassar pada tahun 2018 yaitu sebanyak 9 Kantor Akuntan Publik.

Tabel 1. Daftar Nama Kantor Auditor Publik (KAP)

\begin{tabular}{|c|c|c|c|c|}
\hline No. & Nama KAP & Alamat & No. Izin & $\begin{array}{l}\text { Jumlah } \\
\text { Auditor }\end{array}$ \\
\hline 1. & $\begin{array}{l}\text { KAP Drs. Rusman Thoeng, M.Com, } \\
\text { BAP }\end{array}$ & Jl. Rusa, No. 65 A, Maricaya & $\begin{array}{l}\text { KEP- } \\
064 / \text { KM.6/2004 }\end{array}$ & 7 \\
\hline 2. & $\begin{array}{l}\text { KAP Benny, Tony, Frans \& Daniel } \\
\text { (Cab) }\end{array}$ & Jl. Nuri No.30, Mariso & 247/KM.1/2011 & 5 \\
\hline 3. & $\begin{array}{l}\text { KAP Thomas, Blasius, Widartoyo } \\
\text { \& Rekan (Cab) }\end{array}$ & $\begin{array}{l}\text { Jl Boulevard Ruko Jascinth } \\
\text { I No } 10 \text { Panakkukang }\end{array}$ & 41/KM.1/2010 & 6 \\
\hline 4. & KAP Drs. Harly Weku & $\begin{array}{l}\text { Komp. Ruko Dewi, Jalan } \\
\text { Bontosua No. } 1 \text { D }\end{array}$ & $\begin{array}{l}\text { KEP.058/KM.17/1 } \\
999\end{array}$ & 4 \\
\hline 5. & KAP Yakub Ratan, CPA & Jl. Mesjid Raya No. 80 A & 1158/KM.1/2010 & 5 \\
\hline 6. & $\begin{array}{l}\text { Dra. Ellya Noolisyati Dan Rekan } \\
\text { (Cab) }\end{array}$ & $\begin{array}{l}\text { Jl. A.P.Pettarani Ruko } \\
\text { Diamond Center No.44, } \\
\text { Makassar }\end{array}$ & 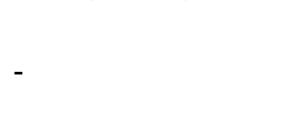 & 5 \\
\hline 7. & KAP Yaniswar \& Rekan & Jl. Langgau 8/12, Makassar & - & 5 \\
\hline 8. & KAP Usman \& rekan (Cab) & Jl. Maccini Tgh No. 21 & $\begin{array}{l}\text { KEP- } \\
\text { 992/KM.17/1998 }\end{array}$ & 6 \\
\hline 9. & $\begin{array}{l}\text { KAP Bharata, Arifin, Mumajad \& } \\
\text { Sayuti (Cab) }\end{array}$ & $\begin{array}{l}\text { Jl. H. Andi Mappanyuki No. } \\
121\end{array}$ & 855/KM.1/2012 & 2 \\
\hline \multicolumn{4}{|c|}{ Jumlah } & 45 \\
\hline
\end{tabular}

Sumber : www.iapi.com, (2018)

Pengambilan sampel dilakukan dengan menggunakan teknik sensus, dimana peneliti mengambil seluruh anggota populasi sebagai respondennya yakni 45 orang auditor dari 9 Kantor Akuntan Publik Di Makassar. Data dikumpulkan dengan melakukan penyebaran kuesioner yang telah disusun secara terstruktur mengenai tanggapan Fee Audit, Resiko Audit, Kualitas Audit, serta Skeptisme Profesional para auditor. Data yang dikumpulkan dan diolah dalam penelitian ini adalah data primer dan data sekunder. Data primer yang diperoleh dari jawaban auditor dan data sekunder yang diperoleh dari bukti tertulis dan literature kepustakaan. Untuk mendapatkan data yang dibutuhkan dalam penelitian ini digunakan instrumen berupa kuesioner, yang diadopsi dari beberapa penelitian terdahulu dan akan dimodifikasi sesuai dengan kebutuhan penelitian.

Metode statistik yang digunakan untuk menguji hipotesis adalah dengan menggunakan regresi linier berganda dengan bantuan perangkat lunak SPSS for windows 16.00 , setelah semua data-data dalam penelitian ini terkumpul, maka selanjutnya dilakukan analisis data yang terdiri dari Uji Statistik deskriptif, uji validitas, uji reliabilitas, uji multikolinearitas, uji normalitas, uji heterokedastisitas dan dan selanjutnya dilakukan uji hipotesis melalui uji persamaan regresi linear berganda dan moderated regression analysis dengan persamaan matematis untuk hubungan tersebut dapat dirumuskan sebagai berikut:

$\mathrm{Y}=\alpha+\beta 1 \mathrm{X} 1+\beta 2 \mathrm{X} 2+\beta 3(\mathrm{X} 1 * \mathrm{M})+\beta 4(\mathrm{X} 2 * \mathrm{M})+\varepsilon$ 
Keterangan :

$\begin{array}{ll}\text { Y } & : \text { Kualitas Audit } \\ \alpha & : \text { Konstanta } \\ \beta & : \text { Koefisien Regresi } \\ \text { X1 } & \text { : Fee Audit } \\ \text { X2 } & \text { : Resiko Audit } \\ \text { X3 } & \text { :Skeptisme Profesional } \\ \varepsilon & : \text { Error }\end{array}$

$(\mathrm{X} 1 * \mathrm{M})=$ Interaksi antara fee audit dengan kualitas audit

$(\mathrm{X} 2 * \mathrm{M})=$ Interaksi antara risiko audit dengan kualitas audit

Dalam penelitian ini dilakukan uji koefisien determinasi (R2) untuk mengukur seberapa jauh kemampuan model dalam menerangkan variasi variabel dependen.Dalam penelitian ini dilakukan uji T dan uji F untuk melihat pengaruh variable yang diukur secara parsial maupun secara simultan.

\section{Hasil dan pembahasan}

Setelah melakukan penyebaran kuesioner kepada seluruh responden penelitian. Data yang berhasil dibagikan secara langsung kepada responden adalah hanya 8 Kantor Akuntan Publik yang bersedia dengan responden sebanyak 40 orang.

Hasil Uji Instrumen Penelitian

Sebuah instrumen dikatakan valid apabila instrumen tersebut dapat digunakan untuk mengukur apa yang seharusnya diukur (Sugiyono, 2009). Dasar pengukuran validitas adalah jika hasil pengujian menunjukkan nilai rhitung > rtabel maka item tersebut dikatakan valid dan dapat digunakan untuk penelitian selanjutnya. Pada tabel 1 berikut disajikan data hasil analisis validitas instrument. Berdasarkan tabel 2, dapat diketahui besarnya koefisien korelasi dari seluruh butir pernyataan terdiri dari masingmasing 1 butir pernyataan terhadap variabel X. Dari hasil perhitungan koefisien korelasi seluruhnya mempunyai nilai probabilitas yang lebih kecil dari 0,05. Dengan demikian dapat disimpulkan bahwa seluruh butir pernyataan dinyatakan valid.

Tabel 2. Hasil Uji Validitas

\begin{tabular}{|c|c|c|c|}
\hline Instrumen & Prob & $A=5 \%$ & Ket \\
\hline \multicolumn{4}{|l|}{ Fee Audit ( $\left.\mathrm{X}_{1}\right)$} \\
\hline 1. $\mathrm{FA}_{1}$ & 0,000 & 0,05 & Valid \\
\hline 2. $\mathrm{FA}_{2}$ & 0,000 & 0,05 & Valid \\
\hline 3. $\mathrm{FA}_{3}$ & 0,000 & 0,05 & Valid \\
\hline 4. $\mathrm{FA}_{4}$ & 0,000 & 0,05 & Valid \\
\hline \multicolumn{4}{|l|}{ Risiko Audit ( $\mathrm{X}_{2}$ ) } \\
\hline 1. $\mathrm{RA}_{1}$ & 0,000 & 0,05 & Valid \\
\hline 2. $\mathrm{RA}_{2}$ & 0,000 & 0,05 & Valid \\
\hline 3. $\mathrm{RA}_{3}$ & 0,000 & 0,05 & Valid \\
\hline \multicolumn{4}{|l|}{ Kualitas Audit (Y) } \\
\hline 1. $\mathrm{KA}_{1}$ & 0,000 & 0,05 & Valid \\
\hline 2. $\mathrm{KA}_{2}$ & 0,000 & 0,05 & Valid \\
\hline 3. $\mathrm{KA}_{3}$ & 0,000 & 0,05 & Valid \\
\hline 4. $\mathrm{KA}_{4}$ & 0,000 & 0,05 & Valid \\
\hline \multicolumn{4}{|l|}{ Skeptisme Profesional Auditor } \\
\hline 1. $\mathrm{SP}_{1}$ & 0,000 & 0,05 & Valid \\
\hline 2. $\mathrm{SP}_{2}$ & 0,000 & 0,05 & Valid \\
\hline 3. $\mathrm{SP}_{3}$ & 0,000 & 0,05 & Valid \\
\hline 4. $\mathrm{SP}_{4}$ & 0,000 & 0,05 & Valid \\
\hline
\end{tabular}

Sumber: data diolah, Tahun 2018

Uji reliabilitas merupakan bentuk uji kualitas data apakah kuesioner dapat diandalkan atau reliable. Suatu instrument penelitian dapat dikatakan reliabel (andal), jika alpha lebih besar dari 0,60. 
Tabel 3. Hasil Uji Reliabilitas Variabel Penelitian

\begin{tabular}{llccc}
\hline \multicolumn{1}{c}{ Variabel } & Koefisien Alpha Cronbach & Nilai Kritis & Ket \\
\hline 1. & Fee Audit & 0,797 & 0,60 & Reliability \\
2. & Risiko Audit & 0,752 & 0,60 & Reliability \\
3. & Kualitas Audit & 0,795 & 0,60 & Reliability \\
4. & Skeptisme Profesionalisme & 0,795 & 0,60 & Reliability \\
& Auditor & & & \\
\hline
\end{tabular}

Sumber: data diolah, Tahun 2018

Berdasarkan ringkasan hasil uji reliabilitas seperti yang terangkum dalam tabel 2, dapat diketahui bahwa nilai koefisien Cronbach Alpha secara keseluruhan nilainya diatas 0,60 (nilai > 0,60), sehingga butirbutir pernyataan dalam kuesioner variabel penelitian dapat digunakan untuk melakukan penelitian selanjutnya

Untuk menjamin data dari responden penelitian telah berdistribusi normal secara normal, maka dilakukan pengujian normalitas data dengan menggunakan analisa grafik normal P-P Plot of Regression Standardized Residual terhadap masing-masing variabel independen, dependen dan moderating.

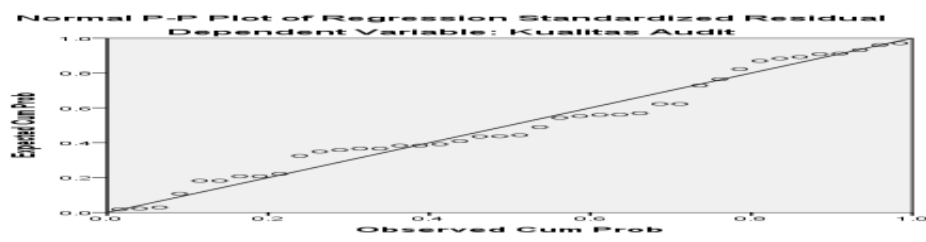

Gambar 1. Normal P-P Plot Regression Standardized Residual Sumber: Data diolah, Tahun 2018

Berdasarkan gambar 2, terlihat seluruh data telah berdistribusi secara normal pada seluruh variabel, baik pada variabel independen maupun variabel dependen. Data menyebar di sekitar garis diagonal dan mengikuti arah garis diagonalnya, maka model regresi memenuhi asumsi normalitas dan data dinyatakan terdistribusi normal.

Uji asumsi kenormalan dapat juga dilihat dari histogram dan normal probability plot antara kualitas audit sebagai variabel dependen dengan Regression Standardized Residual. dimana dapat dilihat bahwa sebagian besar data berada dalam kurva normal, sehingga dapat dikatakan bahwa data yang dianalisis memenuhi syarat normalitas.

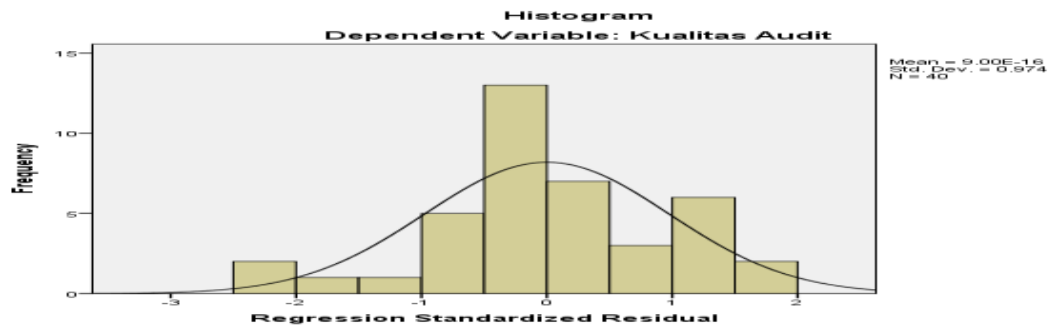

Gambar 2. Histogram \& Regression Standardized Residual Sumber: Data diolah, Tahun 2018

Multikolinearitas yang berarti adanya hubungan linear yang sempurna atau pasti, di antara beberapa atau semua variabel yang menjelaskan dari model regresi. Pendeteksian multikolinearitas dapat dilakukan melalu nilai VIF. Jika nilai VIF lebih besar dari 10 (VIF > 10), maka diperkirakan terjadi multikolinear, namun jika nilai VIF lebih kecil 10 (VIF < 10), maka diperkirakan tidak terjadi multikolinear.

Tabel 3. Hasil Uji Multikolinearitas

\begin{tabular}{|c|c|c|c|}
\hline No & Variabel & VIF & Keterangan \\
\hline 1 & Fee Audit & 1,003 & Tidak ada multikolinearitas \\
\hline 2 & Risiko Audit & 1,003 & Tidak ada multikolinearitas \\
\hline
\end{tabular}

Sumber: data diolah, Tahun 2018 
Hasil pengujian multikoleniaritas dengan menggunakan nilai VIF (variance inflation factor) atas kinerja pegawai, dapat disimpulkan bahwa tidak terdapat adanya permasalahan multikoleniaritas dalam model regresi karena nilai VIF (variance inflation factor) tidak melebihi angka 10.

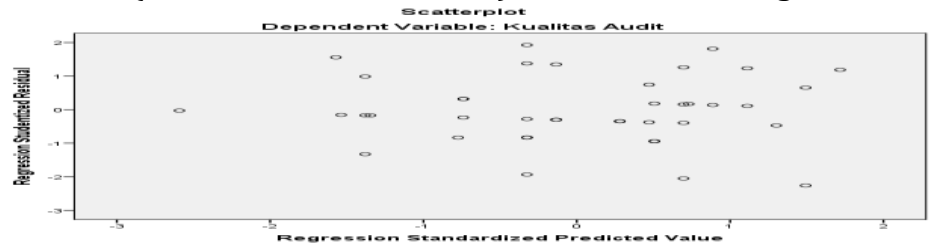

Gambar 4. Scatterplot Penyebaran Residual

Sumber: data diolah, Tahun 2018

Uji Hipotesis Model I

Tabel 4. Hasil Uji Determinasi

Model Summary

\begin{tabular}{|c|c|c|c|c|}
\hline Model & $\mathrm{R}$ & R Square & Adjusted R Square & $\begin{array}{l}\text { Std. Error of the } \\
\text { Estimate }\end{array}$ \\
\hline 1 & $.112^{\mathrm{a}}$ & .013 & -.041 & 1.84656 \\
\hline
\end{tabular}

a. Predictors: (Constant), Risiko Audit, Fee Audit

Berdasarkan tabel 4 , terlihat nilai $\mathrm{R} 2=0,013$. Ini berarti, pengaruh variabel fee audit dan risiko audit terhadap variabel kualitas audit sebesar 1,3\% dan pengaruh variabel lainnya sebesar 98,7\%. Pengaruh ini tergolong tidak baik karena lebih kecil dari 50\% dan signifikan (Pvalue) = 0,000 (sangat jauh dibawah nilai kritis pengujian $\alpha=0,05$ ).

Tabel 5. Hasil Uji Simultan

\begin{tabular}{llrrrrr}
\hline Model & & Sum of Squares & Df & Mean Square & F & Sig. \\
\hline 1 & Regression & 1.613 & 2 & .806 & .236 & $.791^{\mathrm{b}}$ \\
& Residual & 126.162 & 37 & 3.410 & & \\
& Total & 127.775 & 39 & & & \\
\hline
\end{tabular}

a. Dependent Variable: Kualitas Audit

b. Predictors: (Constant), Risiko Audit, Fee Audit

Tabel 6. Hasil Uji Parsial

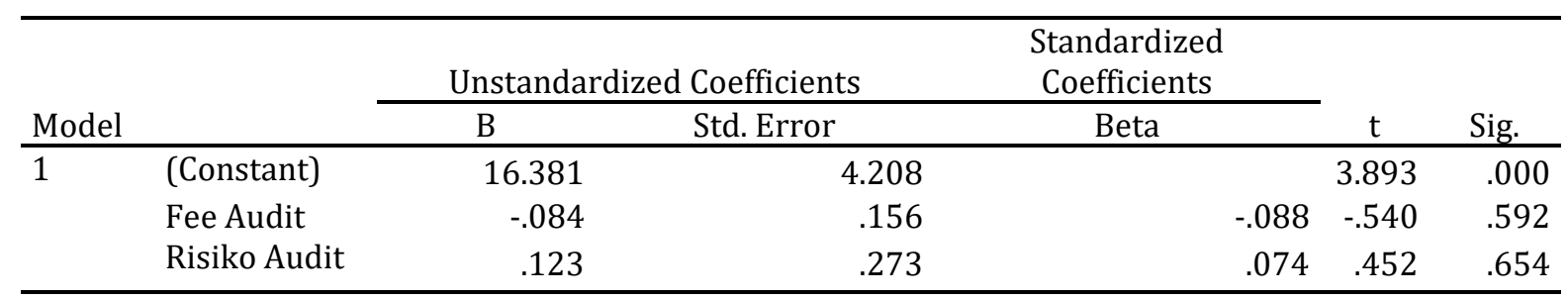

a. Dependent Variable: Kualitas Audit

Berdasarkan tabel 5, secara simulatan variabel fee audit dan risiko audit berpengaruh positif dan tidak signifikan terhadap variabel kualitas audit. Nilai Fhitung sebesar 0,236 dengan level signifikansi 0,791 atau nilai pvalue $>0,05$.

Tabel 6 menunjukkan secara parsial, semua variabel analisis memiliki probabilitas (level signifikansi) yang berbeda-beda.

1. Variabel fee audit memiliki pengaruh negatif dan tidak signifikan terhadap kualitas audit pada Kantor Akuntan Publik di Makassar, berdasarkan hasil pengujian secara parsial dengan menggunakan nilai thitung untuk variabel fee audit sebesar -0,540 dengan tingkat signifikansi 0,592 (p > 5\%). Hasil pengujian ini menyimpulkan bahwa hipotesis yang diajukan ditolak.

2. Variabel risiko audit memiliki pengaruh positif dan tidak signifikan terhadap kualitas audit pada Kantor Akuntan Publik di Makassar, berdasarkan hasil pengujian secara parsial dengan menggunakan nilai thitung untuk variabel risiko audit sebesar 0,452 dengan tingkat signifikansi 0,654 (p > 5\%). Hasil pengujian ini menyimpulkan bahwa hipotesis yang diajukan ditolak. 
Dari hasil analisis yang diperoleh semua variabel yang memiliki koefisien regresi tidak berbeda nyata dengan nol, atas dasar hasil tersebut, persamaan regresi yang diperoleh dapat dipakai untuk melakukan pendugaan statistik, termasuk untuk melakukan peramalan dan persamaan regresi yang diperoleh adalah:

$\mathrm{Y}=16,381-0,084 \mathrm{X} 1+0,123 \mathrm{X} 2$

Persamaan regresi berganda dapat dijelaskan sebagai berikut:

1. Koefisien b0 = 16,381 artinya apabila variabel fee audit (X1) dan risiko audit (X2) tidak mengalami perubahan (konstan), maka kualitas audit pada Kantor Akuntan Publik di Makassar tidak akan berubah.

2. Koefisien b1 $=-0,084$ artinya setiap peningkatan variabel fee audit (X1), maka dapat menurunkan kualitas audit (Y) sebesar 8,4\% dan variabel risiko audit (X2) konstan.

3. Koefisien $\mathrm{b} 2=0,123$ artinya setiap peningkatan variabel risiko audit (X2), maka dapat meningkatkan kualitas audit (Y) sebesar 12,3\% dan variabel fee audit (X1) konstan.

\section{Uji Hipotesis Model II}

Analisis regresi yang diperoleh dapat dipakai untuk melakukan pendugaan statistik untuk pengukuran pengaruh. Pengaruh simultan variabel Xi terhadap variabel Y dapat diketahui juga dari koefisien determinasi serentak (R2). Ini dapat diketahui dari hasil analisis Determinasi Simultan pada tabel sebagai berikut:

Tabel 7. Hasil Uji Determinasi

\begin{tabular}{lrrrr} 
Model & R & R Square & Adjusted R Square & Std. Error of the Estimate \\
\hline 1 & $.932^{\mathrm{a}}$ & .869 & .858 & .68164 \\
\hline
\end{tabular}

a. Predictors: (Constant), Zscore: Skeptisme, Zscore: Risiko Audit, Zscore: Fee Audit

Tabel 7 menjelaskan bahwa nilai $\mathrm{R} 2=0,869$. Ini berarti, pengaruh variabel fee audit dan risiko audit secara simultan terhadap variabel Y (kualitas audit) adalah 86,9\% dan pengaruh variabel lainnya sebesar 13,1\%. Pengaruh ini tergolong baik karena lebih besar dari 50\% dan signifikan (Pvalue) = 0,000 (sangat jauh dibawah nilai kritis pengujian $\alpha=0,05$ ).

Pengujian secara simultan (uji F) dilakukan untuk mengetahui apakah semua variabel independen Xi (fee audit dan risiko audit) secara simultan memiliki pengaruh yang signifikan pada variabel dependen kualitas audit (Y) pada Kantor Akuntan Publik di Makassar. Apabila H0 diterima, maka koefisien beta regresi tidak berbeda nyata dengan 0 sehingga hasil regresi yang diperoleh tidak dapat dipakai untuk melakukan pendugaan statistik dan tidak dapat dipakai untuk mengukur, apakah variabel independen Xi berpengaruh terhadap variabel terikat Yi. Sebaliknya, apabila H0 ditolak atau Ha diterima, maka koefisien beta regresi berbeda nyata dengan 0 sehingga hasil regresi yang diperoleh dapat dipakai untuk melakukan pendugaan statistik. Dengan demikian persamaan regresi dapat dipakai untuk mengukur, apakah variabel independen Xi berpengaruh terhadap variabel terikat Yi.

Tabel 8. Hasil Uji Simultan

\begin{tabular}{|c|c|c|c|c|c|c|}
\hline \multicolumn{2}{|c|}{ Model } & \multirow{2}{*}{$\begin{array}{r}\text { Sum of Squares } \\
111.048\end{array}$} & \multirow{2}{*}{ df 3} & \multirow{2}{*}{$\frac{\text { Mean Square }}{37.016}$} & \multirow{2}{*}{$\frac{F}{79.667}$} & \multirow{2}{*}{$\begin{array}{l}\text { Sig. } \\
.000^{\mathrm{b}}\end{array}$} \\
\hline 1 & Regression & & & & & \\
\hline & Residual & 16.727 & 36 & .465 & & \\
\hline & Total & 127.775 & 39 & & & \\
\hline
\end{tabular}

a. Dependent Variable: Kualitas Audit

b. Predictors: (Constant), Zscore: Skeptisme, Zscore: Risiko Audit, Zscore: Fee Audit

Tabel 8, menjelaskan bahwa variabel fee audit dan risiko audit berpengaruh positif dan signifikan terhadap variabel dependen Y (kualitas audit). Nilai Fhitung sebesar 79,667 dengan level signifikansi 0,000 atau nilai pvalue $<0,05$. Berdasarkan kriteria pengujian hipotesis, maka H0 ditolak dan Ha diterima. Ini berarti secara simultan semua variabel independen memiliki perbedaan nyata dengan 0 .

Penyajian atas hasil analisis tersebut dimaksudkan untuk mengemukakan persamaan regresi yang diperoleh dalam penelitian 
Tabel 9. Hasil Uji Parsial Variabel X1

\begin{tabular}{|c|c|c|c|c|c|c|}
\hline \multirow{2}{*}{\multicolumn{2}{|c|}{ Model }} & \multicolumn{2}{|c|}{$\begin{array}{l}\text { Unstandardized } \\
\text { Coefficients }\end{array}$} & \multirow{2}{*}{$\begin{array}{c}\text { Standardized } \\
\text { Coefficients } \\
\text { Beta } \\
\end{array}$} & \multirow[b]{2}{*}{$\mathrm{t}$} & \multirow[b]{2}{*}{ Sig. } \\
\hline & & $\mathrm{B}$ & Std. Error & & & \\
\hline \multirow[t]{4}{*}{1} & (Constant) & 16.754 & .173 & & 96.597 & .000 \\
\hline & Zscore: Fee Audit & -.007 & .108 & -.004 & -.063 & .950 \\
\hline & Zscore: Skeptisme & 1.705 & .108 & .942 & 15.779 & .000 \\
\hline & Moderating & -.156 & .120 & -.078 & -1.298 & .203 \\
\hline
\end{tabular}

a. Dependent Variable: Kualitas Audit

Dari tabel 9, terlihat bahwa secara parsial diperoleh hasil dengan nilai $\mathrm{t}=-1,298$ dengan tingkat signifikansi 0,203 yang berarti skeptisme professional auditor tidak mampu memoderasi (memperkuat dan memperlemah) hubungan antara variable fee audit terhadap kualitas audit

Tabel 10. Hasil Uji Parsial Variabel X2

\begin{tabular}{|c|c|c|c|c|c|c|}
\hline \multirow{2}{*}{\multicolumn{2}{|c|}{ Model }} & \multicolumn{2}{|c|}{$\begin{array}{l}\text { Unstandardized } \\
\text { Coefficients }\end{array}$} & \multirow{2}{*}{$\begin{array}{c}\text { Standardized } \\
\text { Coefficients } \\
\text { Beta } \\
\end{array}$} & \multirow[b]{2}{*}{$\mathrm{t}$} & \multirow[b]{2}{*}{ Sig. } \\
\hline & & B & Std. Error & & & \\
\hline \multirow[t]{4}{*}{1} & (Constant) & 16.811 & .185 & & 90.959 & .000 \\
\hline & Zscore: Risiko Audit & .010 & .106 & .005 & .093 & .926 \\
\hline & Zscore: Skeptisme & 1.680 & 106 & .928 & 15.827 & .000 \\
\hline & Moderating & -.213 & 138 & -.091 & -1.545 & .131 \\
\hline
\end{tabular}

a. Dependent Variable: Kualitas Audit

Dari tabel 10, terlihat bahwa secara parsial diperoleh hasil dengan nilai $t=-1,545$ dengan tingkat signifikansi 0,131 yang berarti skeptisme professional auditor tidak mampu memoderasi (memperkuat dan memperlemah) hubungan antara variabel risiko audit terhadap kualitas audit.

\section{Pembahasan}

Pengaruh Fee Audit terhadap Kualitas Audit

Hasil uji hipotesis menunjukkan bahwa fee audit berpengaruh negatif dan tidak signifikan terhadap kualitas audit. Hal ini disebabkan karena semakin tinggi fee yang didapatkan tetapi semakin rendah kualitas audit yang dihasilkan, karena auditor yang menerima fee audit yang besar cenderung merasa tergantung kepada klien sehingga segan menentang pendapat klien meskipun pendapat klien tersebut tidak sesuai dengan standar pemeriksaan akuntan publik.

Hasil penelitian ini memberikan implikasi bahwa auditor kantor akuntan publik di Kota Makassar tidak menjadikan besaran biaya audit yang diterima tidak serta merta menjadi salah satu wujud meningkatkan kualitas audit yang dihasilkan. Hasil penelitian ini tidak mendukung penelitian Yuniarti (2011); Nindita \& Siregar (2013); dan El-Gammal (2012) yang menemukan adanya pengaruh positif dan signifikan fee audit terhadap kualitas audit.

\section{Pengaruh Risiko Audit terhadap Kualitas Audit}

Hasil uji hipotesis menunjukkan bahwa risiko audit berpengaruh negatif dan tidak signifikan terhadap kualitas audit. Hal ini disebabkan karena risiko kesalahan audit yang meningkat dan kualitas audit yang dihasilkan menurun. Ini dapat terjadi karena adanya kesalahan materil dalam proses audit, ketika integritas manajemen klien sulit ditemukan karena adanya kepentingan pihak manajemen yang ingin mencapai tujuan-tujuan tertentu melalui laporan keuangan yang salah tersebut.

Hasil penelitian ini memberikan implikasi bahwa tingkat risiko audit yang tinggi akan mengakibatkan auditor mengahadapi tugas yang semakin kompleks dan dapat berdampak pada rendahnya kualitas audit yang dihasilkan auditor. Hasil penelitian ini mendukung penelitian Ariningsih dan Mertha (2017); Adnyani dan Latrini (2017); Pratama dan Merkusiwati (2015) dimana peneliti menemukan adanya pengaruh negatif dan signifikan risiko audit terhadap kualitas audit

\section{Pengaruh Fee Audit terhadap Kualitas Audit dengan Skeptisme Profesional Auditor Sebagai Variabel Moderating \\ Hasil penelitian ini menunjukkan bahwa skeptisme profesional auditor sebagai variabel moderasi tidak mampu memperkuat pengaruh fee audit terhadap kualitas audit. Hal ini disebabkan karena kualitas}


audit yang rendah akibat auditor tidak mengevaluasi kemungkinan kecurangan material, dikarenakan fee yang sangat besar membuat auditor takut akan kehilangan sebagian pendapatannya, dan tentu saja sikap skeptisme seorang auditor tidak berlaku ketika hal ini terjadi.

\section{Pengaruh Risiko Audit terhadap Kualitas Audit dengan Skeptisme Profesional Auditor Sebagai Variabel Moderating \\ Hasil penelitian ini menunjukkan bahwa skeptisme profesional auditor sebagai variabel moderasi tidak mampu memperkuat pengaruh risiko audit terhadap kualitas audit. Hal ini disebabkan karena walaupun seorang auditor memiliki sikap skeptis yang selalu mempertanyakan dan meragukan bukti audit, kemungkinan tidak diketemukannya kesalahan materil dalam pemeriksaan masih bisa terjadi. Komponen dari resiko ini sepenuhnya berada dibawah kontrol auditor. Kemungkinan auditor tidak dapat menemukan kesalahan materil disebabkan karena auditor pemeriksa tidak melakukan pemeriksaan dengan sepenuhnya}

\section{Simpulan dan saran}

Hasil penelitian ini menemukan variable fee audit dan risiko audit berpengaruh negatif dan tidak signifikan terhadap kualitas audit. Hasil ini memberikan gambaran bahwa semakin tinggi fee audit yang diterima auditor maka kualitas audit akan semakin menurun. Hasil ini juga memberikan gambaran bahwa semakin tinggi risiko audit maka kualitas audit akan semakin menurun. Skeptisme profesional auditor sebagai variabel moderasi tidak mampu memperkuat pengaruh fee audit terhadap kualitas audit. selanjutnya skeptisme profesional auditor sebagai variabel moderasi juga tidak mampu memperkuat pengaruh risiko audit terhadap kualitas audit.

Hasil dari penelitian ini diharapkan dapat memberikan masukan dan pertimbangan bagi KAP terkait untuk lebih meningkatkan hasil kerja audit yang berkualitas. Sampel dalam penelitian ini masih tergolong sedikit dan hanya terbatas pada auditor yang bekerja di kantor akuntan publik di Makassar, oleh karena itu disarankan kepada penelitian selanjutnya agar dapat menambah serta memperluas wilayah dan jumlah sampel. Penggunaan waktu yang tepat dalam penyebaran kuesioner juga menjadi faktor yang cukup penting untuk diperhatikan karena informasi dari auditor yang ditemui adalah bahwa pada awal tahun, auditor sangat sibuk dalam melaksanakan tugasnya sehingga tidak fokus dalam menjawab kuesioner

\section{Daftar Rujukan}

Adnyani, N. K. S., \& Latrini, M. Y. (2017). Pengaruh Risiko Kesalahan, Akuntabilitas, dan Due Professional Care pada Kantor Akuntan Publik Provinsi Bali. E-Jurnal Akuntansi Universitas Udayana, 18(1), 117144.

Anugerah, R. (2014). Pengaruh kompetensi, mtivasi dan skeptisme profesional terhadap kualitas audit auditor ispektorat se-provinsi Riau. Jom Fekon, 1(2), 1-19.

Ariningsih, P. S., \& Mertha, I. M. (2017). Pengaruh Independensi , Tekanan Anggaran Waktu , Risiko Audit , Dan Gender Pada Kualitas Audit. E-Jurnal Akuntansi, 18(2), 1545-1574. Retrieved from https://ojs.unud.ac.id/index.php/Akuntansi/article/view/25813

Attamimi, F. M., \& Riduan, A. (2015). Faktor-faktor yang mempengaruhi Skeptisisme Profesional Auditor. Jurnal Ilmu \& Riset Akuntansi, 4(7), 1-22.

Cahyadi P. I. G. (2013). Kualitas Audit Kantor Akuntan Publik Di Baditinjau Dari Time Budget Pressure, Risiko Kesalahan, Dan Kompleksitas Audit. Jurnal Ilmiah Akuntansi Dan Humanika, 2 nomer 2(UNDIKSHA), 765-784.

Diana, H., \& Azlina, N. (2016). Pengaruh tekanan anggaran, waktu, risiko audit, locus of control dan komitmen profesional terhadap perilaku penurunan kualitas audit ( reduced audit quality behavior. Jurnal Akuntansi, 4(2), 176-188.

El-Gammal, W. (2012). Determinants of Audit Fees: Evidence from Lebanon. International Business Research, 5(11), 136-145. https://doi.org/10.5539/ibr.v5n11p136

Hartadi, B. (2012). PENGARUH FEE AUDIT, ROTASI KAP, DAN REPUTASI AUDITOR TERHADAP KUALITAS AUDIT DI BURSA EFEK INDONESIA. EKUITAS (Jurnal Ekonomi Dan Keuangan). https://doi.org/10.24034/j25485024.y2012.v16.i1.2315

Jemada, M. V, \& Yaniartha, P. D. S. (2013). Pengaruh Tekanan Anggaran Waktu, Kompleksitas Tugas Dan Reputasi Auditor Terhadap Fee Audit Pada Kantor Akuntan Publik (KAP) DI Bali. E-Jurnal Akuntansi Universitas Udayana, 3(3), 132-146.

Johnson, P. E., Jamal, K., \& Glen Berryman, R. (1989). Audit judgment research. Accounting, Organizations and Society, 14(1-2), 83-99. https://doi.org/10.1016/0361-3682(89)90035-4 
Julianto, I. K. A., Yadnyana, I. K., \& Suputra, I. D. G. D. (2016). Pengaruh Audit Fee, Perencanaan Audit, Dan Risiko Audit Terhadap Kualitas Audit Pada Kantor Akuntan Publik Di Bali. E-Jurnal Ekonomi Dan Bisnis Universitas Udayana, 12, 4029-4056.

Kurniasih, M., \& Rohman, A. (2014). Pengaruh fee Audit, Audit Tenure, Dan Rotasi Audit Tehadap Kualitas Audit. 3, 1-10.

Nindita, C., \& Siregar, S. V. (2013). Analisis Pengaruh Ukuran Kantor Akuntan Publik Terhadap Kualitas Audit di Indonesia. Jurnal Akuntansi Dan Keuangan, 14(2), 91-1014. https://doi.org/10.9744/jak.14.2.91-104

Noviyanti, S. (2008). Skeptisme Profesional Auditor Dalam Mendeteksi Kecurangan. Jurnal Akuntansi Dan Keuangan Indonesia, 5(I), 102-125.

Oktania, R., \& Suryono, B. (2013). Faktor-faktor yang berpengaruh terhadap Skeptisisme Profesional Auditor. Jurnal Ilmu \& Riset Akuntans, 2(12), 1-21.

Pratama, I. M. I., \& Merkusiwati, N. K. L. A. (2015). Pengaruh Time Budget Pressure, Risiko Kesalahan Audit, dan Masa Perikatan Audit Terhadap Kualitas Audit Pada Kantor Akuntan Publik di Daerah Bali. EJurnal Akuntansi, 11(1), 211-219.

Rohmaniyah. (2016). Penentuan Fee Audit Terhadap Independensi Auditor. AKTIVA Jurnal Akuntansi Dan Investasi, 1(2), 190-204.

Srimindarti, C. (2006). Opini Audit Dan Pergantian Auditor: Kajian Berdasarkan Resiko, Kemampuan Perusahaan Dan Kinerja Auditor. Fokus Ekonomi, 5(1), 64-76.

Suraida, I. (2005). Pengaruh Etika, Kompetensi, Pengalaman Audit dan Risiko Audit terhadap Skeptisisme Profesional Auditor dan Ketepatan Pemberian Opini Akuntan Publik (Ida Suraida). Sosiohumaniora, $7(3), 186-202$.

Tarigan, M. U., Bangun, P., \& Susanti. (2013). Pengaruh Kompetensi, Etika, dan Fee Audit Terhadap Kulaitas Audit. Akuntansi, 13(April), 803-832.

Yuniarti, R. (2011). Audit Firm Size, Audit Fee and Audit Quality. Journal of Global Management, 2(1), 8497. 